Marta Grech'

Andrés Visintin'

Magdalena Laurito'

Elizabet Estallo'

Pablo Lorenzo"I

Irene Roccia'II

Maximiliano Korin"II

Facundo Goya'II

Francisco Ludueña-Almeida'

Walter Almirón'

Centro de Investigaciones Entomológicas de Córdoba. Facultad de Ciencias Exactas, Físicas y Naturales. Universidad Nacional de Córdoba. Córdoba, Argentina

Sede Universitaria Chepes. Universidad Nacional de La Rioja. Chepes, Argentina

III Epidemiología-Salud Ambiental. Subsecretaría de Salud. Neuquén, Argentina

Correspondence:

Marta Grech

Av. Vélez Sarsfield 1611

X5016GCA Córdoba, Argentina

E-mail: grechmarta@gmail.com

\section{New records of mosquito species (Diptera: Culicidae) from Neuquén and La Rioja provinces, Argentina}

\section{Novo registro de mosquitos (Diptera: Culicidae) nas províncias de Neuquén e La Rioja, Argentina}

\begin{abstract}
The presence of Aedes aegypti is reported beyond its current limit of distribution in Argentina, in the city of Neuquén, Neuquén Province. Ovitraps were placed to collect Ae. aegypti eggs between December 2009 and April 2010. The geographical distribution of Culex eduardoi, Psorophora ciliata and Ps. cingulata is extended with new records from two provinces.
\end{abstract}

DESCRIPTORS: Insect Vectors. Aedes aegypti. Culex eduardoi. Psorophora ciliata. Psorophora cingulata. Argentina.

\section{RESUMO}

Relata-se a presença de Aedes aegypti ao sul de seu limite atual de distribuição na Argentina, na cidade de Neuquén, província de Neuquén. Ovitrampas foram instaladas de dezembro/2009 a abril/2010. A distribuição geográfica de Culex eduardoi, Psorophora ciliata e Ps. cingulata aumenta, incluindo novos registros para duas províncias.

DESCRITORES: Insetos Vetores. Aedes aegypti. Culex eduardoi. Psorophora ciliata. Psorophora cingulata. Argentina.

\section{INTRODUCTION}

Several mosquito species stand out because of their medical importance as reservoirs and vectors of pathogens of diseases such as dengue, yellow fever, malaria, filariasis and encephalitis. Knowledge of their distribution is of paramount importance for control programs as it is essential to determine areas of potential risk of disease transmission, especially for species of public health concern. This study aimed to report new mosquito species from Neuquén (southwest) and La Rioja (northwest) provinces in Argentina. 


\section{METHODS}

Data were obtained from an entomological surveillance project for Aedes aegypti carried out in the city of Neuquén by the local health department, and from the National University of La Rioja research project conducted to update the mosquito fauna in La Rioja Province.

Samples of Ae. aegypti eggs were collected using ovitraps. An ovitrap consisted of a 1000 -mL plastic cup lined with a layer of brown colored filter paper. Ovitraps were filled with a dry grass infusion $(750 \mathrm{~mL} /$ ovitrap) to increase the likelihood of attracting gravid females. ${ }^{a}$ Forty ovitraps were placed in the urban area of Neuquén city, near a bus station and surrounding area, and in lowlying areas $(<1.5 \mathrm{~m}$ high), and were weekly replaced from December 2009 to April 2010. The eggs collected, from only three ovitraps that were active during January and March, were kept on moist filter paper for at least four to five days to ensure embryogenesis, and later were transferred to the Centro de Investigaciones Entomológicas de Córdoba (Universidad Nacional de Córdoba, Argentina) for rearing.

Immature stages belonging to other mosquito species were collected from natural water bodies at ground level using a 300-mL dipper in both La Rioja and Neuquén provinces. Larvae were individually reared, as appropriate, to obtain larvae and associated pupal exuviae and adults. Species were identified from larvae, males and females, as described by Darsie (1985). Information on locality and date of collection, altitude above sea level (in meters), phytogeographical region, climate, number and stage of the specimens collected, and collectors were recorded for each species. Life stages and other terms used are abbreviated as follows: male (M); male genitalia (MG); female (F); pupa (P); pupal exuviae $(\mathrm{Pe})$; fourth-instar larva (L); larval exuviae (Le); eggs (E); person making the determination of the species (det.), and collector (coll.).

Voucher specimens confirming these new records are deposited in the mosquito collection of Centro de Investigaciones Entomológicas de Córdoba (Universidad Nacional de Córdoba, Argentina).

\section{RESULTS}

Aedes (Stegomyia) aegypti (L.). Neuquén Province: Neuquén city (38 $57^{\circ}$ 'S, $68^{\circ} 03^{\prime} \mathrm{W}$; WGS 84; $271 \mathrm{~m}$ );
January, March 2010; Monte phytogeographical region, cold semiarid climate (average yearly temperature $14.7^{\circ} \mathrm{C}$, July mean temperature $\left.5.6^{\circ} \mathrm{C}\right) ; 39 \mathrm{E}, 2 \mathrm{~L}, 4 \mathrm{M}$, $1 \mathrm{~F}$; colls: Roccia and Korin; det: Laurito and Almirón.

Culex (Culex) eduardoi Casal \& García. Neuquén Province: Neuquén city $\left(38^{\circ} 57^{\prime} \mathrm{S}, 68^{\circ} 03^{\prime} \mathrm{W}\right.$, WGS 84 ; $271 \mathrm{~m}$ ); December 2009; Monte phytogeographical region, cold semiarid climate (average yearly temperature $14.7^{\circ} \mathrm{C}$, July mean temperature $5.6^{\circ} \mathrm{C}$ ). $4 \mathrm{MG}, 3$ Pe, 13 L, 5 Le; colls: Roccia and Korin; det: Laurito.

Psorophora (Psorophora) ciliata (Fabricius). La Rioja Province: Milagro ( $30^{\circ} 58^{\prime} \mathrm{S}, 65^{\circ} 37^{\prime} \mathrm{W}$, WGS 84; 715 m); March 2010; Chaco phytogeographical region, arid climate of hills and fields; 2 F, 2 L; colls: Visintin and Lorenzo; det: Visintin.

Psorophora (Grabhamia) cingulata (Fabricius). La Rioja Province: Ambil ( $31^{\circ} 01^{\prime} \mathrm{S}, 66^{\circ} 14^{\prime} \mathrm{W}$, WGS 84; $715 \mathrm{~m}$ ); February 2011; Chaco phytogeographical region, arid climate of hills and fields; 2 M, 2 F; colls: Visintin and Lorenzo; det: Visintin.

\section{DISCUSSION}

Dengue is a major mosquito-borne viral disease, and is widely distributed in tropical and subtropical regions. Ae. aegypti is currently the vector of dengue virus in Argentina and neighboring countries, and was the vector of yellow fever virus in the past. During 2009 there was an epidemic of dengue-1 serotype in the central and northwestern provinces of Argentina with more than 25.000 reported cases. ${ }^{b}$ Aedes aegypti was previously reported in subtropical and temperate areas in central and north Argentina. In 1930, before the implementation of the Ae. aegypti eradication program in the Americas, this species had been reported as south as the city of Bahía Blanca $\left(38^{\circ} 44^{\prime} \mathrm{S}, 62^{\circ} 16^{\prime} \mathrm{W}\right.$, WGS 84 ) in Buenos Aires Province. ${ }^{\circ}$ In the last years, it has spread towards the west to San Luis Province, ${ }^{10}$ and south to Santa Rosa city ( $36^{\circ} 35^{\prime}$ 'S, $64^{\circ} 16^{\prime} \mathrm{W}$, WGS 84 ) in La Pampa Province. ${ }^{8}$ Ae. aegypti has not been recently reported in Bahía Blanca city where entomological surveys were performed as well. ${ }^{\mathrm{d}}$ Our study reports the presence of Ae. aegypti in Neuquén Province, in the Patagonia region, being the southernmost record in Argentina. However, the finding of Ae. aegypti eggs does not imply that the mosquito is now established in Neuquén city. The eggs collected were probably laid by female mosquitoes that moved between cities due to

a Reiter P, Nathan MB. Guías para la evaluación de la eficacia del rociado especial de insecticidas para el control del vector del dengue $A$. aegypti. Geneva: World Health Organization; 2003 [cited 2010 Mar 15]. Available from: http://whqlibdoc.who.int/hq/2003/WHO_CDS_ CPE_PVC_2001.1_spa.pdf

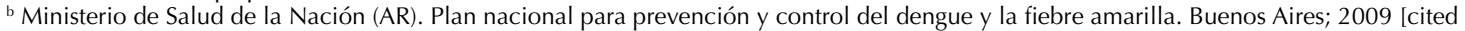
2009 Aug 05]. Available from: http://www.msal.gov.ar/dengue/descargas/plan_nacional\%20_prevencion_control_dengue_f_amarilla.pdf c Schweigmann N, Boffi R. Aedes aegypti y Aedes albopictus: situación entomológica en la región. In: Temas de zoonosis y enfermedades emergentes. Segundo Congreso Argentino de Zoonosis y Primer Congreso Argentino y Lationoamericano de Enfermedades Emergentes Buenos Aires. 1998; p. 259-63.

¿ Municipalidad de Bahía Blanca. Subsecretaría de Gestión Ambiental. Saneamiento ambiental. Identificación del mosquito transmisor del virus del dengue. Buenos Aires; 2011 [cited 2011 Apr 15]. Available from: http://www.bahiablanca.gov.ar/saneamiento/aedes_dengue.php 
travel and commerce. They completed embryogenesis under local environmental conditions in Neuquén city, similar to that seen in Bahía Blanca city (average yearly temperature $15.4^{\circ} \mathrm{C}$, July average temperature $7.6^{\circ} \mathrm{C}$ ) where Ae. aegypti was previously reported.

It is yet unknown the epidemiological importance of Cx. eduardoi. However, their breeding sites are often found next to urban areas. ${ }^{7} \mathrm{Cx}$. eduardoi has previously spread south from Buenos Aires Province to the temperate cold and dry area of Chubut Province, ${ }^{2}$ and Santa Cruz Province, ${ }^{9}$ being the first record from Neuquén Province. These mosquitoes along with other three species of Culex (Cx. pipiens, Cx. dolosus, and $C x$. acharistus) can be as widespread as the Patagonia region, southern Argentina. ${ }^{9}$

Psorophora are widespread pest mosquitoes and several species are vectors of arboviruses. Psorophora ciliata has not been yet incriminated in any disease transmission. However, females of this species are large and aggressive mosquitoes, attacking any time, and inflicting a painful injury. The larvae of Ps. ciliata

\section{REFERENCES}

1. Anderson CR, Aitken THG, Downs WG. The isolation of Ilhéus virus from wild caught forest mosquitoes in Trinidad. Am J Trop Med Hyg. 1956;5(4):621-5.

2. Burroni $N$, Loetti $V$, Freire $G$, Jensen $O$, Schweigmann N. New record and larval habitats of Culex eduardoi (Diptera: Culicidae) in an irrigated area of Patagonia, Chubut Province, Argentina. Mem Inst Oswaldo Cruz. 2004;102(2):237-9. DOI:10.1590/S007402762007005000009

3. Carpenter SJ, La Casse WJ. Mosquitoes of North America (North of Mexico). Berkeley: University of California Press; 1955.

4. Darsie Jr RF. The mosquitoes of Argentina: Part I. Keys for identification of adult females and fourth stage larvae in English and Spanish (Diptera: Culicidae). Mosq Syst. 1985;17(1):153-253.

5. Forattini OP. Entomologia Médica. Culicini: Culex, Aedes, Psorophora. São Paulo: Edusp; 1965. v.2.

6. Lopes J, Lozovei AL. Ecologia de mosquitos (Diptera, Culicidae) em criadouros naturais e artificiais de área rural do norte do Parana, Brasil. II. Coletas com are predacious on other medically important mosquito larvae occurring in the same breeding sites such as Aedes taeniorrhynchus, Ps. ferox and Ps. confinnis. ${ }^{3,5}$ In Argentina, Ps. ciliata was previously reported in subtropical and temperate areas of the country, with La Pampa Province as its southernmost limit of distribution. ${ }^{8}$ This species is reported for the first time in the semiarid area of La Rioja Province.

It is unknown the epidemiological importance of Psorophora cingulata. However, Ilheus virus was isolated from a pool of Psorophora spp. mosquitoes from Trinidad, where Ps. cingulata was present. ${ }^{1}$ This mosquito species has the ability to adapt to anthropogenic environments, and this feature could have major epidemiological implications. ${ }^{6}$ This is the western record of PS. cingulata in Argentina, being reported for the first time in La Rioja Province, semiarid region.

This is the first record of the presence of Ae. aegypti in Neuquén Province. There is a need for effective surveillance measures to prevent the establishment of this mosquito in southern Argentina.

isca humana. Rev Bras Zool. 1996;13(3):585-96. DOI:10.1590/S0101-81751996000300007

7. Lopes J. Ecologia de mosquitos (Diptera, Culicidae) em criadouros naturais e artificiais de área rural do norte do Paraná, Brasil. VIII. Influência das larvas predadoras (Toxorhynchites sp., Limatus durhamii e Culex bigoti) sobre a população de larvas de Culex quinquefasciatus e Culex eduardoi. Rev Bras Zool. 1999;16(3):821-6. DOI:10.1590/S0101-81751999000300018

8. Rossi GC, Lestani EA, D'Oria JM. Nuevos registros y distribución de mosquitos de la Argentina (Diptera: Culicidae). Rev Soc Entomol Argent. 2006;65(3-4):51-6.

9. Rossi GC, Vezzani D. An update of mosquitoes of Argentine Patagonia with new distribution records. J Am Mosq Control Assoc. 2011; 27(2):93-8. DOI:10.2987/10-6082.1

10. Visintin AM, Laurito M, Díaz LA, Benítez Musicant G, Cano C, Ramírez R, et al. New records of mosquito species for Central and Cuyo regions in Argentina. J Am Mosq Control Assoc. 2009;25(2):208-9. DOI:10.2987/08-5702.1

The study was supported by grants from Fondo para la Investigación Científica y Tecnológica (FONCyT - PICT 38060), Concejo Nacional de Investigaciones Científicas y Técnicas (CONICET), Secretaría de Ciencia y Tecnología, Universidad Nacional de Córdoba (SECYT), and Secretaria de Salud de la Província de Neuquén.

Grech $M$ is supported by CONICET (grant: Beca Interna de Postgrado Tipo II).

Laurito $M$ and Estallo E are supported by CONICET (grant: Beca Interna Postdoctoral).

Almirón W is supported by CONICET (Independent researcher).

The authors declare no conflicts of interests. 